ISSN 2616-7328 (Online); ISSN 2409-904X (Print)

Kitaêznavčì doslìdžennâ, 2019, No. 2, pp. 29-37

doi: https://doi.org/10.15407/chinesest2019.02.029

UDC 339.942

\title{
CHINA'S OVERSEAS SPECIAL ECONOMIC ZONES: EXPERIENCE OF THE REPUBLIC OF BELARUS
}

\section{O. Drobotiuk}

Ph.D. in Economics,

Kyiv National Economic University named after Vadym Hetman Institute for Contemporary China Studies named after Borys Kurts 03057, Kyiv, 54/1 Peremohy prospect

khomenko@kneu.edu.ua

\section{Monashova}

International Humanitarian and Economic Institute, 129A, Mayakovskogo St., 220028, Minsk, Belarus

One of the key levers for attracting foreign capital and realizing the export potential in developing countries is special economic zones, within which a favorable investment climate is ensured due to the special tax regime, preferences in financial support for export and innovative activities of companies - preferential lending rates, government financing.

In the early 1980 s, the Chinese government began to actively create special economic zones in coastal cities, which in the future ensured the influx of foreign capital, the development of industry, the creation of new jobs, rapid economic growth and improving the quality of life of the population. In 2006, the Chinese government initiated the creation of overseas economic zones to expand its own experience in industrialization and facilitate trade and economic cooperation with other countries of the world. In the modern "One Belt, One Road" Initiative, the development of overseas zones of economic and trade cooperation and overseas industrial parks is one of the new forms of partnership between China and host countries.

The article is devoted to topical issues in the development of trade and economic relations between the PRC and developing countries. The work explores the experience of creating foreign special economic China in developing countries, in particular in the Republic of Belarus. An analysis is made of the economic development of the Republic of Belarus as a result of the creation of the China-Belarus Great Stone Industrial Park on its territory.

Keywords: China, special economic zones, industrial park, Great Stone, Belarus, economic development

\section{ЗАКОРДОННІ СПЕЦІАЛЬНІ ЕКОНОМІЧНІ ЗОНИ КНР: ДОСВІД РЕСПУБЛІКИ БІЛОРУСЬ}

\section{О. В. Дроботюк, В. Ю. Монашова}

Зони $з$ преференційним інвестиційним режимом - один із ключових рушіїв залучення іноземного капіталу та реалізації експортного потенціалу в країнах, що розвиваються. У світовій практиці спеціальні економічні зони

C 2019 O. Drobotiuk and V. Monashova; Published by the A. Yu. Krymskyi Institute of Oriental Studies, NAS of Ukraine and the Ukrainian Association of Sinologists on behalf of The Chinese Studies. This is an Open Access article distributed under the terms of the Creative Commons Attribution License (https://creativecommons.org/licenses/by-nc-nd/4.0/). 
(СЕ3) виступають дієвим інструментом залучення інвестицій. Адже це є територія 3 пільговим податковим режимом та економічними преференціями. Відповідно до класифікації Світового Банку виокремлюють: зони вільної торгівлі (ЗВТ); експортні зони (ЕЗ); вільні економічні зони (ВЕ3); індустріальні парки (ІП); вільні порти (ВП); митні логістичні парки (МЛП); міські підприємницькі зони (МПЗ).

Історично найбільш поширені зони вільної торгівлі. Починаючи з 1990-х років розпочалася нова хвиля розвитку СЕЗ - поява зон техніко-економічного розвитку та індустріальних парків. Передумовою стала економіка знань і активізація інноваційної активності в промислово розвинених країнах та країнах, що розвиваються. Зокрема, ключовими гравцями стали США, Японія, Південна Корея та КНР.

За даними UNCTAD, на сьогодні у світі нараховується 5383 спеціальні економічні зони у 147 країнах світу, три четверті з яких - країни, що розвиваються. Зокрема високотехнологічні та інноваційні спеціалізовані індустріальні зони зосереджені переважно в країнах, що розвиваються, а СЕЗ, які спрямовані на логістику, - в розвинутих країнах. Крім того, в останні роки кількість СЕЗ зростає швидкими темпами та станом на 2019 рік щонайменше 500 CE3 перебувають на стадії розробки [UNCTAD 2019].

Таблиия 1

Число спеціальних економічних зон у світі в 2019 році

\begin{tabular}{|l|r|r|r|}
\hline \multicolumn{1}{|c|}{ Класифікація країн } & Кількість СЕ3 & $\begin{array}{l}\text { Кількість СЕ3 } \\
\text { у розробці }\end{array}$ & $\begin{array}{c}\text { Кількість } \\
\text { планових СЕ3 }\end{array}$ \\
\hline Світ & $\mathbf{5 3 8 3}$ & $\mathbf{4 7 4}$ & $\mathbf{5 0 7}$ \\
\hline Розвинуті країни & $\mathbf{3 7 4}$ & $\mathbf{5}$ &.. \\
\hline Свропа & 105 & 5 &.. \\
\hline Північна Америка & 262 &.. &.. \\
\hline Країни, що розвиваються & $\mathbf{4 7 7 2}$ & $\mathbf{4 5 1}$ & $\mathbf{5 0 2}$ \\
\hline Азія & 4046 & 371 & 419 \\
\hline КНР & 2543 & 13 &.. \\
\hline Індія & 373 & 142 & 53 \\
\hline Африка & 237 & 51 & 24 \\
\hline Латинська Америка та & 486 & 28 & $\mathbf{5}$ \\
\hline Карибські острови & $\mathbf{2 3 7}$ & $\mathbf{1 8}$ & \\
\hline Країни з перехідною економікою & & & \\
\hline
\end{tabular}

Джерело: [UNCTAD 2019]

Відповідно до звіту UNCTAD “World Investment Report 2019” у Китаї сконцентровано майже половину від світової кількості спеціальних економічних зон. Однією $з$ ключових передумов такого лідерства $є$ Політика реформ та відкритості, яка бере свій початок у 1978 році, коли китайська економіка була закритою, а частка зовнішньої торгівлі у структурі ВВП становила $9 \%$. СЕЗ стали інструментом стимулювання економічного розвитку депресивних регіонів та Китаю в цілому. Засновуючись на позитивному досвіді азійських країн, у 1979 році Державна рада ухвалила рішення про створення чотирьох пілотних спеціальних економічних зон: Шеньчжень, Чжухай, Сямень, Гуандун. Одними з ключових завдань економічних реформ у КНР стали залучення іноземних інвестицій, нарощення експорту та подолання асиметрії розвитку регіонів. 
Пілотні СЕ3 показали позитивний ефект у нагромадженні інвестицій та у нарощенні промислового виробництва, тому в межах реалізації регіональної політики 1984 року уряд ініціював відкриття спеціальних економічних зон у 14 приморських містах від Даляня до Бейхая.

На початку 2000-х Китай ініціює створення закордонних економічних зон із метою розширення власного досвіду індустріалізації та сприяння торговельно-економічній співпраці з іншими країнами світу. У 2006 році, як частину Одинадцятого п'ятирічного плану, Китай оголосив про програму створення 50 зон зарубіжного економічного та торговельного співробітництва, яка включала в себе прискорену внутрішню економічну реструктуризацію Китаю та просування за ланцюгом створення вартості, надання підтримки малому та середньому підприємництву для здійснення інтернаціональної діяльності; досягнення стратегічних цілей, зокрема співпрацю Південь-Південь, обмін промисловим досвідом з іншими країнами; уникнення митних бар'єрів для китайського експорту шляхом перенесення виробництва за кордон [Farole 2011; Farole \& Akinci 2011].

Закордонні зони торговельно-економічного співробітництва $є$ одним із ключових механізмів у рамках китайської ініціативи “Один пояс, один шлях" задля поглиблення інвестиційної кооперації. Уряд КНР заохочує китайські підприємства брати участь у створенні спеціальних економічних зон за кордоном через відкриту систему тендерів. На сьогоднішній день Міністерством комерції КНР верифіковано 20 зарубіжних економічних та торговельних зон, які створено китайськими інвестиційними організаціями уздовж "Одного поясу, одного шляху” та в африканських країнах: 7 у Південно-Східній Азії, по 4 в РФ та Африці, по 2 в Центральній Азії та Угорщині, 1 - у Південній Азiї [Ministry of Commerce PRC 2019a].

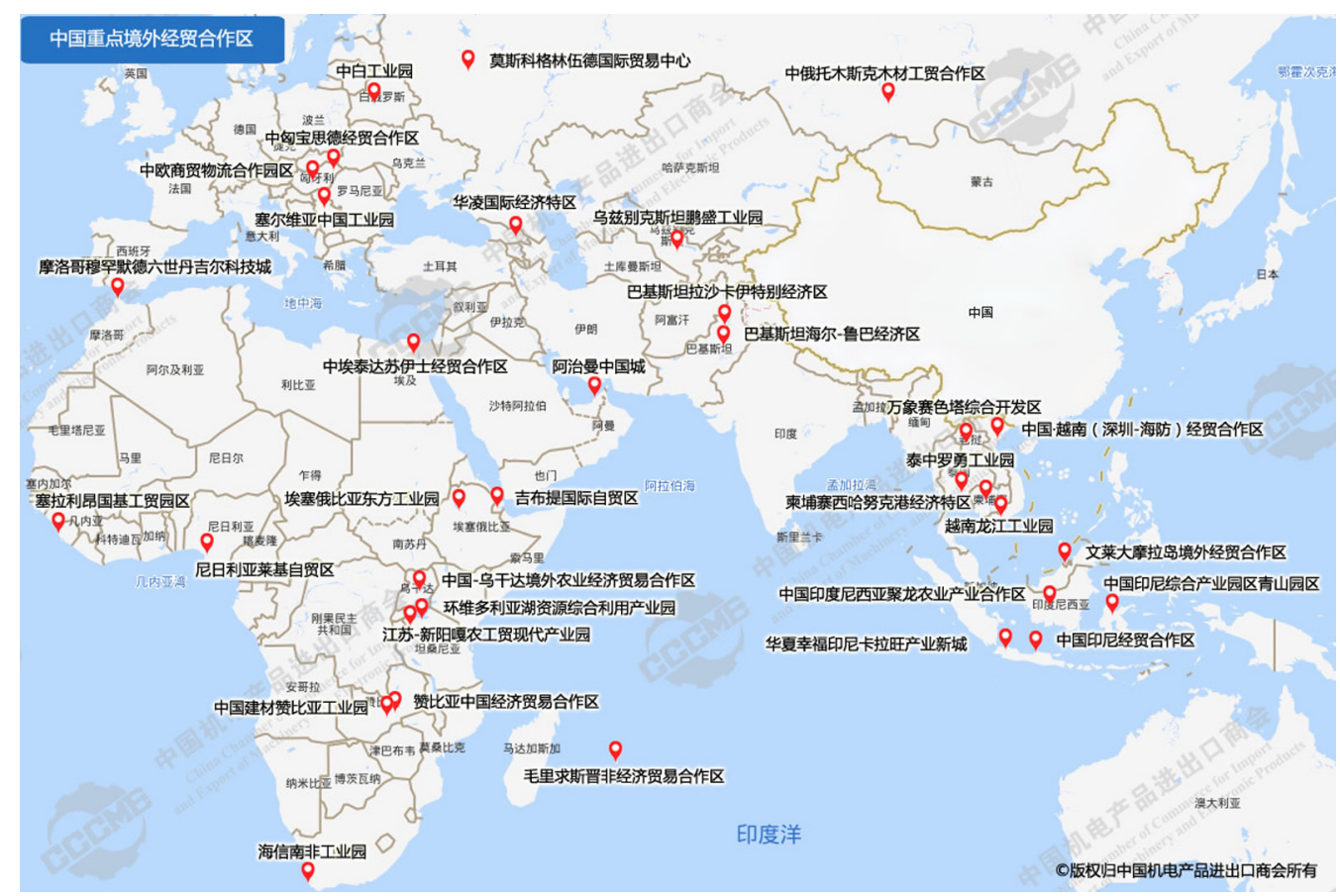

Рис. 1. Мапа закордонних спеціальних економічних зон КНР Джерело: [Zhōng guó jìng wài jīng mào hé zuò qū, 2019] 
Згідно з даними Міністерства комерції КНР, станом на листопад 2019 року, загальний обсяг інвестицій у закордонні зони торговельно-економічної співпраці становив 41 млрд дол., функціонує 5400 підприємств, які сплатили 4,3 млрд податків, та створено 370 тис. робочих місць у країнах базування CE3 [Ministry of Commerce PRC 2019].

Окрім зарубіжних зон економічного та торговельного співробітництва, за межами Китаю функціонує 99 китайських індустріальних парків, які також $є$ CE3, затверджених Міністерством комерції КНР [Overseas Industrial Parks 2018]. До таких належить і Китайсько-Білоруський індустріальний парк "Великий камінь", який був заснований у 2012 р. (з 2018 року - СЕ3) та розвивався як міжурядовий партнерський проект. Успішним прикладом, який передував “Великому каменю”, був Сінгапурсько-китайський індустріальний парк в Сучжоу (1994) як результат спільних інвестицій сінгапурського та китайського консорціумів [UNCTAD 2019].

Китайсько-білоруський індустріальний парк “Великий камінь” (ВК) призначений для високотехнологічних інвесторів не тільки з Білорусі та КНР, але з інших країн, зокрема резидентами вже є підприємства Австрії, Німеччини, РФ, США та інші. Станом на кінець 2019 року нараховувалося 59 резидентів ВК. Пріоритетними напрямами підприємницької діяльності резидентів ВК є машинобудування, електроніка та телекомунікації, тонка хімія, біотехнології, нові матеріали, логістика, фармацевтика, електронна комерція, зберігання та обробка великого масиву інформації, соціально-культурна діяльність, здійснення НДДКР. Саме ці напрямки відповідають загальній тенденції діяльності в СЕЗ у країнах, що розвиваються.

Невід'ємним інструментом залучення прямих іноземних інвестицій є податкові преференції, зокрема в Китайсько-Білоруському індустріальному парку надають такі пільги:

- Політика "10+": нульова ставка податку на прибуток на 10 років та наступна його сплата за ставкою, зниженою вдвічі до 2062 року;

- Нульова ставка земельного податку на період роботи підприємств (до 2062);

- Нульова ставка податку на нерухомість на період роботи підприємств (до 2062);

- Митні ПДВ та мита: нульова ставка на товари для старту проєкту та при експорті товарів за межі САEC;

- Податок на дивіденди: нульова ставка протягом 5 років від моменту оголошення прибутку;

- Податок із доходів фізичних осіб: 9 \%;

- Відрахування у фонд соиіального захисту населення: 35 \% від середньої заробітної плати в країні (не від фактично нарахованої);

- ПДВ: повернення з бюджету.

Завдяки податковим пільгам та гарантіям стабільності і незмінності умов у період з 2015 по 2018 рр. до Індустріального парку залучено іноземних інвестицій обсягом понад 180 млн дол. (без врахування китайської допомоги розвитку, інвестицій Great Stone Development Company та уряду Республіки Білорусь) [Kolkin 2018; National Statistical Committee of the Republic of Belarus 2019]. 
Основні показники діяльності Китайсько-Білоруського індустріального парку "Великий камінь"

\begin{tabular}{|c|c|c|c|}
\hline Показники & $\begin{array}{c}\text { Січень - } \\
\text { вересень } \\
2018 \text { р. }\end{array}$ & $\begin{array}{c}\text { Січень - } \\
\text { вересень } \\
2019 \text { р. }\end{array}$ & $\begin{array}{l}\text { Січень - вере- } \\
\text { сень } 2019 \text { р. у } \\
\% \text { до січня - } \\
\text { вересня } 2018 \text { р. }\end{array}$ \\
\hline Кількість зареєстрованих резидентів & 37 & 55 & 149 \\
\hline 3 них діючих резидентів & 30 & 43 & 154 \\
\hline Середньооблікова чисельність працівників, осіб & 330 & 612 & 186 \\
\hline $\begin{array}{l}\text { Чисельність працівників, прийнятих на додатко- } \\
\text { во введені робочі місця, осіб }\end{array}$ & 137 & 255 & 186 \\
\hline $\begin{array}{l}\text { Виручка від реалізації товарів, продукції, робіт, } \\
\text { послуг, млн дол.* }\end{array}$ & 6,7 & 17,7 & 266 \\
\hline \multicolumn{4}{|l|}{ у тому числі: } \\
\hline за межі Республіки Білорусь, млн дол. ${ }^{*}$ & 2,5 & 2,1 & 81 \\
\hline $\begin{array}{l}\text { частка в загальному обсязі виручки від } \\
\text { реалізації товарів, продукції, робіт, } \\
\text { послуг, } \%\end{array}$ & 38,1 & 11,5 & $\mathrm{x}$ \\
\hline Чистий прибуток, збиток (-), млн дол. ${ }^{*}$ & $-11,5$ & $-4,9$ & $\mathrm{x}$ \\
\hline $\begin{array}{l}\text { Обсяг прямих інвестицій, що надійшли від іно- } \\
\text { земних інвесторів, млн. дол. }\end{array}$ & 58,7 & 40,0 & 68 \\
\hline Інвестиції в основний капітал, млн дол." & 34,8 & 26,5 & 76 \\
\hline \multicolumn{4}{|l|}{ у тому числі: } \\
\hline $\begin{array}{l}\text { машини, обладнання, транспортні засоби, } \\
\text { інструмент, інвентар, млн дол. }\end{array}$ & 13,4 & 6,5 & 49 \\
\hline $\begin{array}{l}\text { Іноземні джерела інвестицій в основний капітал, } \\
\text { млн дол.* }\end{array}$ & 25,2 & 20,9 & 83 \\
\hline $\begin{array}{l}\text { Обсяг виробництва промислової продукції, робіт, } \\
\text { послуг промислового характеру, у фактичних ці- } \\
\text { нах, млн дол. }\end{array}$ & 5,2 & 11,0 & 211 \\
\hline $\begin{array}{l}\text { Податки, збори та обов’язкові платежі, сплачені в } \\
\text { бюджет і позабюджетні фонди, млн дол.* }\end{array}$ & 0,9 & 3,4 & 363 \\
\hline Експорт товарів, млн дол. & 22,4 & 19,6 & 88 \\
\hline Імпорт товарів, млн дол. & 28,3 & 41,5 & 147 \\
\hline Сальдо зовнішньої торгівлі товарами, млн дол. & $-5,9$ & $-5,9$ & $\mathrm{x}$ \\
\hline
\end{tabular}

* конвертовано за середнім курсом білоруського рубля до долара США: січень - вересень 2018 - 2,0077 BYN/USD; січень-вересень 2019 - 2,0975 BYN/USD.

Джерело: [National Statistical Committee of the Republic of Belarus 2019]

За 9 місяців 2019 року чисельність зареєстрованих резидентів зросла на майже 50 \% порівняно з аналогічним періодом 2018. У тому числі, діючих резидентів налічувалося 43 одиниці на кінець вересня 2019 р. Разом із входженням нових резидентів було створено 255 робочих місць та інвестовано 40 млн дол. 3 січня по вересень 2019 р. Показники зовнішньої торгівлі Індустріального парку свідчать про збільшення обсягів імпорту, що обумовлено нарощенням обсягів виробництва, що потребує високотехнологічного обладнання, яке відповідно імпортується з країн походження інвесторів та інших держав.

\footnotetext{
${ }^{1}$ Дані наведено без урахування діяльності резидентів за межами території Індустріального парку (за винятком показників по зовнішній торгівлі).
} 
3 метою комплексного аналізу впливу Індустріального парку “Великий камінь" на соціально-економічний розвиток Білорусі, а також посилення ролі на міжнародних ринках доцільно проаналізувати макроекономічні показники та індикатори зовнішньоекономічної діяльності країни у динаміці.

У період з 2010 по 2018 рр. середньорічні темпи зростання білоруської економіки становили 1,9 \%. У той же час, інвестиції в реальний сектор Республіки Білорусь зростали в середньому на 8 \% щорічно; валовий зовнішній борг збільшився на 10 відсоткових пунктів у 2018 р. (рис. 2). Варто зазначити, що у 2015 та 2016 роках спостерігався спад білоруської економіки, однією 3 причин якого є зовнішньоторговельні ризики, пов'язані з РФ, тому пошук альтернативних ринків та партнерів є актуальним для Республіки Білорусь.

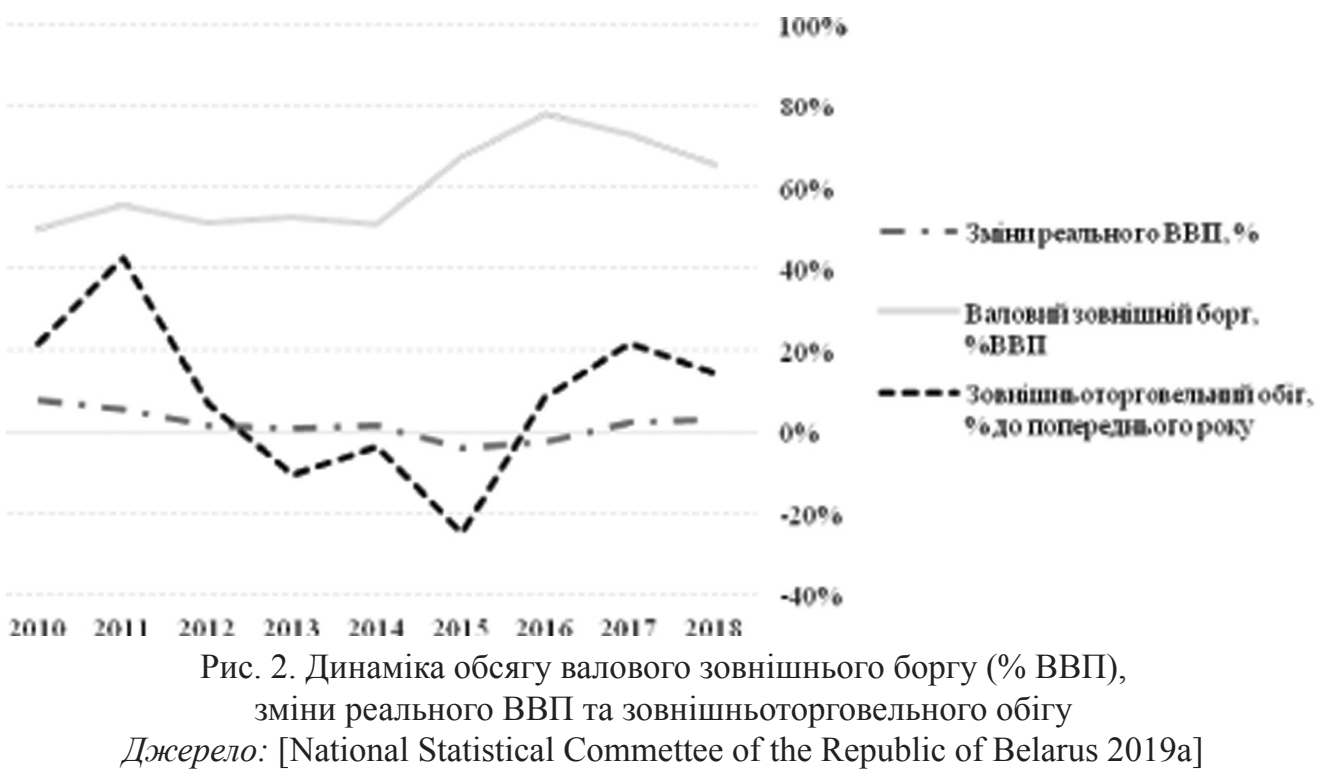

Разом із тим у 2014 році спостерігається подвоєння китайських інвестицій у білоруський реальний сектор економіки, однак їхня частка становила 2 \%. У 2018 році китайські інвестиції у загальному обсязі збільшилися на 1,1 відсоткових пунктів. Білорусь інвестувала в КНР 1,1 \% від загального обсягу власних закордонних інвестицій у 2017 році (рис. 3).

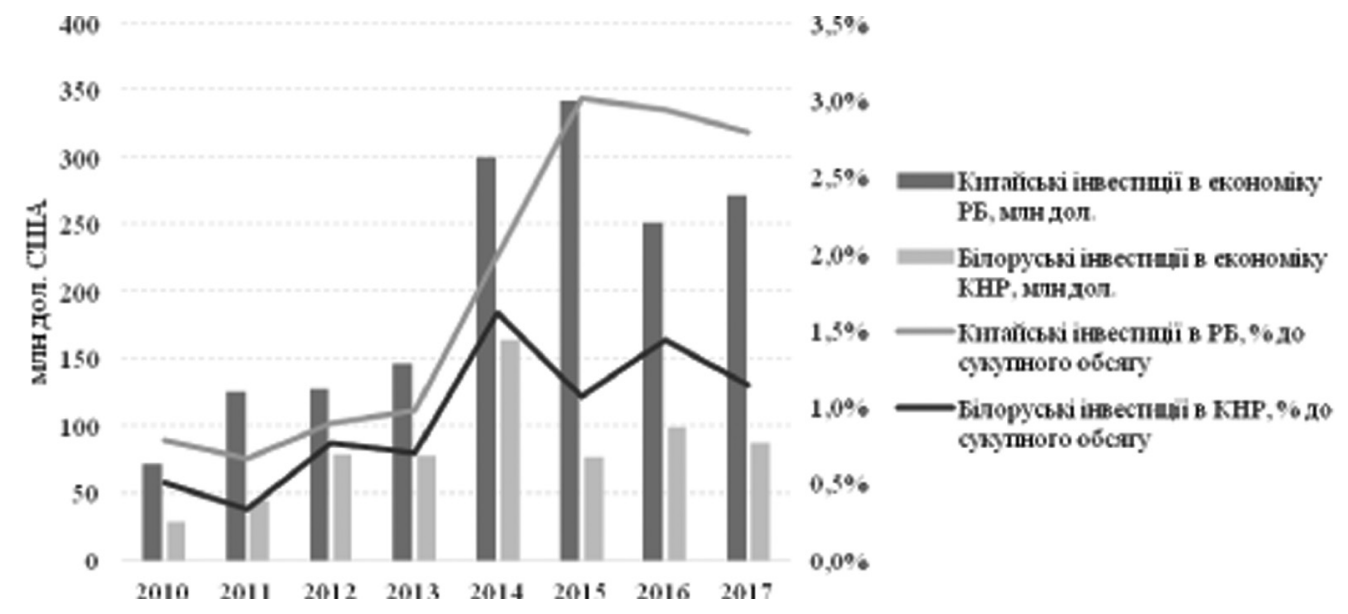

Рис. 3. Динаміка двосторонніх китайсько-білоруських інвестиційних відносин, млн дол. Джерело: [National Statistical Commettee of the Republic of Belarus 2019a] 
Динаміка двосторонніх торговельних відносин демонструє висхідний тренд зміни обсягів імпорту, що обумовлює зростання негативного сальдо торгівлі товарами. Станом на кінець 2018 року частка Китаю у сукупному обсязі імпорту становить $8 \%$, а в експорті - $1 \%$. У географічній структурі імпорту Китай посідає друге місце, на першому - РФ, на третьому - Німеччина; географія експорту така: РФ, Україна, Велика Британія.

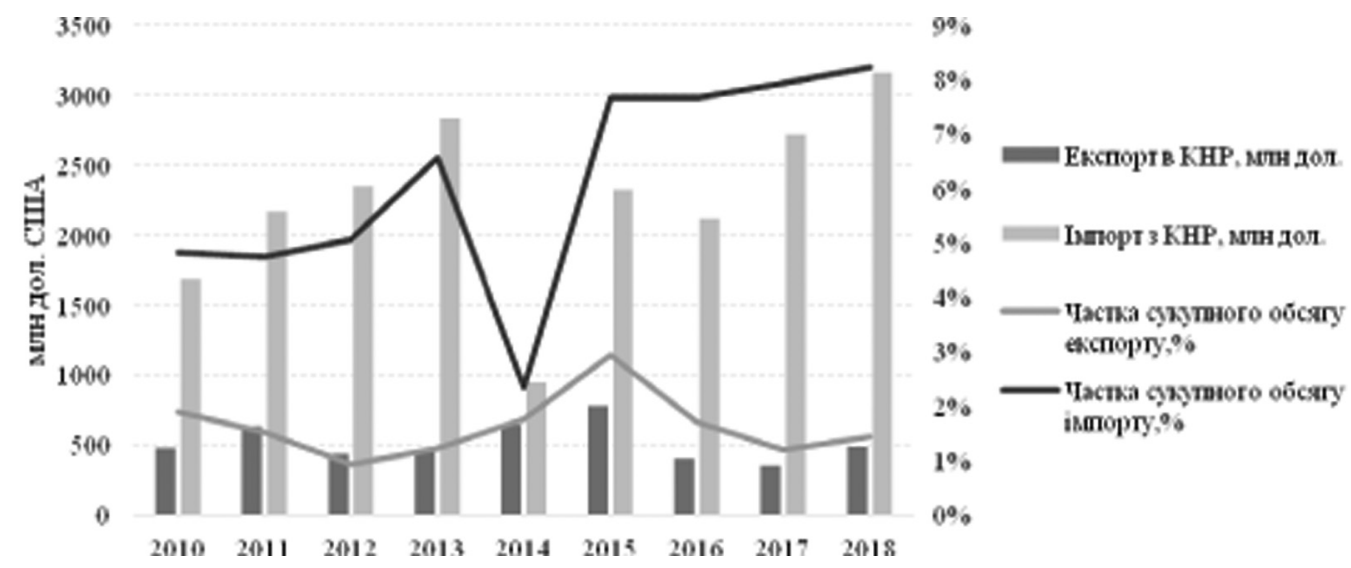

Рис. 4. Динаміка двосторонньої китайсько-білоруської торгівлі товарами, млн дол. Джерело: [National Statistical Commettee of the Republic of Belarus 2019a]

Повертаючись до показників Індустріального парку “Великий камінь”, у 2018 році до СЕЗ надійшло 0,8 \% сукупного обсягу прямих іноземних інвестицій, а частка у зовнішній торгівлі Білорусі становить 0,08 \%, зокрема в експорті - 0,04 \%, імпорті - 0,12\%. Таким чином, розвиток спеціальних економічних зон у країнах, що розвиваються, є інструментом залучення іноземних інвестицій та стимулювання довгострокового сталого розвитку, зокрема через створення нових робочих місць, розбудову інфраструктури, реалізацію високотехнологічних проектів.

Відкриття Китаєм закордонних зон економічного та торговельного співробітництва та індустріальних парків уздовж “Одного поясу, одного шляху” $\epsilon$ однією з нових форм міжнародної співпраці, що дозволяє ефективно здійснювати міжурядове партнерство, базуючись на принципі “win-win”, а також сприяє взаємодії китайського бізнесу з підприємствами приймаючих країн.

\section{REFERENCES}

Farole, T. (2011), "Special Economic Zones: What Have We Learned?" World Bank Economic Premise, 1-5.

Farole, T., \& Akinci, G. (2011), Special Economic Zones: Progress, Emerging Challenges, and Future Directions, World Bank (Directions in Development Series), Washington, D.C.

Kolkin, D. (2018), Belarus: Comparative Research on Industrial Parks and Special Economic Zones, EBRD.

Ministry of Commerce PRC (2019), Outward Investment and Cooperation and Implementation of Foreign Aid Achieved High-quality Development and Made Deep and Solid Progress in the Joint Construction of the Belt and Road Initiative, Retrieved from Yearly Overview XIV for the Commerce Work in 2019: http://english.mofcom.gov.cn/article/newsrelease/significantnews/202001/20200102930804. shtml 
Ministry of Commerce PRC (2019a), Tōngguò quèrèn kăohé de jìngwài jīngmào hézuò qū mínglù, Retrieved from: http://fec.mofcom.gov.cn/article/jwjmhzq/article01.shtml

National Statistical Commettee of the Republic of Belarus (2019a), Statistical Yearbook of the Republic of Belarus, 2019, National Statistical Commettee of the Republic of Belarus, Minsk.

National Statistical Committee of the Republic of Belarus (2019), The main indicators of the activity of the residents of China-Belarus Industrial Park Great Stone, Retrieved from National Statistical Committee of the Republic of Belarus: https://www.belstat.gov.by/en/ofitsialnaya-statistika/macroeconomy-and-environment/small-area-statistics/special-economic-zones/annual-data/the-main-indicators-of-the-activity-of-the-residents-of-china-belarus-industrial-park-greatstone/

Overseas Industrial Parks (2018), Retrieved from: http://shandong.chinadaily. com.cn/2018-05/16/c 227022.htm

UNCTAD (2019), World Investment Report 2019, United Nations Publications, New York.

UNDP (2019), Report on Fostering Sustainable Development through Chinese Overseas Economic and Trade Cooperation Zones along the Belt and Road, UNDP.

Zhōng guó jìng wài jīng mào hé zuò qū (2019), Jìng wài hé zuò qū de tú, Retrieved from Zhōng guó jìng wài jīng mào hé zuò qū: http://www.cocz.org//templates/_subsite/cocz/images/map2.jpg

\section{ЗАКОРДОННІ СПЕЦАЛЬНІ ЕКОНОМІЧНІ ЗОНИ КНР: ДОСВІД РЕСПУБЛІКИ БІЛОРУСЬ}

О. В. Дроботюк, В. Ю. Монашова

Одним із ключових рушіїв залучення іноземного капіталу та реалізації експортного потенціалу в країнах, що розвиваються, виступають спеціальні економічні зони, в межах яких забезпечується привабливий інвестиційний клімат за рахунок сприятливих податкових режимів, преференцій у фінансовій підтримці експортної, інноваційної діяльності компаній - пільгові ставки на кредитування, урядове фінансування. На початку 1980-х років уряд Китаю розпочав активно створювати спеціальні економічні зони в приморських містах, що забезпечило в майбутньому притік іноземного капіталу, розвиток промисловості, створення нових робочих місць, швидке економічне зростання та підвищення якості життя населення. У 2006 році уряд Китаю ініціював створення закордонних економічних зон із метою розширення власного досвіду індустріалізації та сприяння торговельно-економічній співпраці з іншими країнами світу. У сучасній ініціативі “Один пояс, один шлях" розвиток закордонних зон економічного та торговельного співробітництва та індустріальних парків $є$ однією з нових форм співпраці між КНР та приймаючими країнами.

Стаття присвячена актуальним питанням розвитку торговельно-економічних відносин КНР та країн, що розвиваються. У роботі досліджується досвід створення закордонних спеціальних економічних зон Китаю в країнах, що розвиваються, зокрема в Республіці Білорусь. Проаналізовано інвестиційний ефект на економічний розвиток Республіки Білорусь у результаті створення на ії території китайсько-білоруського Індустріального парку “Великий камінь”.

Ключові слова: Китай, спеціальні економічні зони, індустріальний парк, Великий камінь, Білорусь, економічний розвиток 
ЗАРУБЕЖНЫЕ СПЕЦИАЛЬНЫЕ ЭКОНОМИЧЕСКИЕ ЗОНЫ КНР: ОПЫТ РЕСПУБЛИКИ БЕЛАРУСЬ

\section{О. В. Дроботюк, В. Ю. Монашова}

Одним из ключевых рычагов привлечения иностранного капитала и реализации экспортного потенциала в развивающихся странах выступают специальные экономические зоны, в пределах которых обеспечивается благоприятный инвестиционный климат за счет специального налогового режима, преференций в финансовой поддержке экспортной, инновационной деятельности компаний - льготных ставок по кредитованию, правительственного финансирования.

В начале 1980-х годов правительство Китая начало активно создавать специальные экономические зоны в приморских городах, что обеспечило в будущем приток иностранного капитала, развитие промышленности, создание новых рабочих мест, быстрый экономический рост и повышение качества жизни населения. В 2006 году правительство Китая инициировало создание иностранных экономических зон с целью расширения собственного опыта индустриализации и содействия в торгово-экономическом сотрудничестве с другими странами мира. В современной инициативе "Один пояс, один путь" развитие зарубежных зон экономического и торгового сотрудничества и индустриальных парков является одной из новых форм сотрудничества между КНР и принимающими странами.

Статья посвящена актуальным вопросам развития торгово-экономических отношений КНР и развивающихся стран. В работе исследуется опыт создания зарубежных специальных экономических зон Китая в развивающихся странах, в частности в Республике Беларусь. Проведен анализ экономического развития Республики Беларусь в результате создания на ее территории китайско-белорусского Индустриального парка "Великий камень".

Ключевые слова: Китай, специальные экономические зоны, индустриальный парк, Великий камень, Беларусь, экономическое развитие

Ключевые слова: Стаття надійшла до редакиї 14.11.2019 